\title{
$\begin{array}{llllllllllllll}\boldsymbol{P} & U & \boldsymbol{B} & \boldsymbol{L} & \boldsymbol{I} & \boldsymbol{C} & \boldsymbol{A} & \boldsymbol{C} & \boldsymbol{I} & \boldsymbol{O} & \boldsymbol{N} & \boldsymbol{E} & \mathrm{S}\end{array}$ del
}

INSTITUTO INTERNACIONAL DE LITERATURA IBEROAMERICANA

\section{BIBLIOTECA DE ClÁsicos DE AMÉRICA}

Constituirá no sólo una selección de autores y de obras iberoamericanas, sino también una historia de la literatura iberoamericana, en cien tomos. En cada tomo, la selección literaria irá acompañada de un estudio biográfico y crítico, notas explicativas y bibliografía.

Se han publicado los siguientes tomos:

I. Antología poética, de Manuel Gonzá$\begin{array}{ll}\text { Estados } & \text { Otros } \\ \text { Unidos } & \text { países }\end{array}$ lez-Prada . . . . . . 2.50 Dls. $2.00 \mathrm{Dls}$.

II. Prosas y versos, de José Asunción Silva 2.00 ” 1.50 ” III. Cuentos, de Horacio Quiroga . . . 2.50 " 2.00 " IV. Flor de tradiciones, de Ricardo Palma 2.50 " 2.00 ”,

Colección Literaria, Series A y B

Amplia y verdadera antología de la poesia iberoamericana contemporánea, editada por Carlos García-Prada. Se publica en dos series. La Serie A es parte integrante de la REVISTA IBEROAMERICANA, órgano del Instituto Internacional de Literatura Iberoamericana. La Serie B se publicará en cuadernos separados. Todas las selecciones irán acompañadas de estudios y noticias biográficas y bibliográficas.

De la Serie A se han publicado:

$$
\begin{aligned}
& \text { Estados Otros } \\
& \text { Unidos países } \\
& \text { I. } 15 \text { poemas, de Porfirio Barba Jacob . } .50 \mathrm{D} 1 \mathrm{~s} . \quad .40 \mathrm{D} l s \text {. } \\
& \text { III. } 42 \text { poemas, de Luis C. López . . . } .50 \text { ” } .40 \text { ” }
\end{aligned}
$$

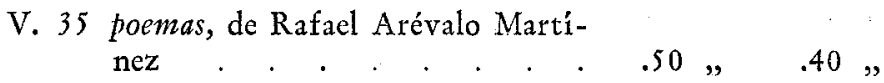

$$
\begin{aligned}
& \text { NINA LEE WEISINGER }
\end{aligned}
$$$$
\text { II. } 16 \text { poemas, de León de Greiff . . . } .50 \text { ” } .40 \text { ”, }
$$$$
\text { IV. } 17 \text { poemas, de Julio Vicuña Cifuentes .50 „ } .40 \text {, }
$$$$
\text { Pedidos a: }
$$$$
\text { University of Texas. Austin, Texas. }
$$ 


\section{NUEVO PRECIO DE NUMEROS ATRASADOS}

DE LA

\section{REVISTA IBEROAMERICANA}

Por el aumento de suscriptores que solicitan los primeros números de REVISTA IBEROAMERICANA y la demanda constante de los mismos, por parte de instituciones y particulares que desean tener sus colecciones completas, se hallan a punto de agotarse los números atrasados, que previsoramente se conservaban.

En vista de ello, el Instituto Internacional de Literatura Iberoamericana se ha visto obligado a aumentar el precio de esos números atrasados de la REVISTA, órgano del mismo.

Los precios fijados, por ahora, a los cuatro primeros números, son los siguientes (en dólares):

\begin{tabular}{lcc} 
Número & Estados Unidos & Otros países \\
\hline & - & - \\
2 y 3 & 2.75 & 2.25 \\
4 & 2.50 & 2.00 \\
5 y siguientes & 2.00 & 1.50 \\
& 1.50 & 1.00
\end{tabular}

Como es fácil advertir por dichos precios, en la venta de esos números atrasados se hacen concesiones análogas a aquellas de que disfrutan los suscriptores de la REVISTA IBEROAMERICANA, fuera de los Estados Unidos.

Pedidos a:

NINA LEE WEISINGER

University of Texas. Austin, Texas. 


\section{$M E M \bigcirc R I A$}

DEL

TERCER CONGRESO INTERNACIONAL DE CATEDRATICOS

$\mathrm{DE}$

\section{LITERATURA IBEROAMERICANA}

Publicada por

UnIVERSIDAd DE TULANE

INSTITUTO INTERNACIONAL DE Literatura IBEROAMERICANA

Tomo de más de 250 páginas y 12 trabajos en torno al tema "E1 nuevo mundo en busca de su expresión"

TRABAJOS:

AUTORES :

La empresa de América y el sentido de la libertad

O homem cósmico de América

Conceitos históticos da Amética brasileita

Crisis europea, cultuta americana

Americanismo y americanidad

México en busca de su expresión

La etetnidad de España en Amética

La democracia en América

Who speaks for New World Democracy

Posición de América

La expresión literaria de América

La poesia hispanoamericana del presente $y$ del potvenit

José María Chacón y Calvo Afrânio Peixoto

Gilberto Freyre

César Barja

Baldomero Sanín Cano

Julio Jiménez Rueda

Federico de Onís

Alberto Zum Felde

Henry Seidel Canby

Alfonso Reyes

Antonio Aita

Arturo Torres-Rioseco

Contiene, además, un Prefacio de Arturo Torres-Rioseco

Discursos de los señores

John E. Englekirk

Alfred Coester

Rufus Carrollton Harris

Carlos García-Prada

Noticias sobre otros trabajos y una documentación completa del programa y de las actas del Congreso

$\$ 3.00$ en los Estados Unidos

$\$ 2.00$ en los demás países

Pedidos a:

MIDDLE AMERICAN RESEARCH INSTITUTE

Tulane University

New Orleans, Louisiana 


\section{MEMORIA}

OF THE SECOND INTERNATIONAL CONGRESS OF PROFESSORS OF IBERO-AMERICAN LITERATURE

An excellent collection of studies in Latin American Literature and Philology which contains contributions by many of the most distinguished scholars in the field from Latin America, Spain, and the United States. Only a limited number of copies are available.

A volume of more than 400 pages.......... 3.50 .

OTHER BOOKS ON HISPANIC SUBJECTS

Grandes novelistas de la América Hispana, with detailed biographical, critical material, and analyses of their works, by Arturo Torres-Rioseco, Professor of Spanish American Literature in the University of California ................... (cloth)

La Novela en la América Hispana, by Arturo Torres-Rioseco .................... (paper)

Don Carlos de Sigïenza y Góngora, a Mexican Savant of the Seventeenth Century, by Irving A. Leonard... . . $\ldots \ldots \ldots \ldots \ldots \ldots \ldots \ldots$ (paper)

Spain's Declining Power in South America, the years 1730-1806, by Bernard Moses. ........... (cloth)

The Civilization of the Americas, by Simpson, Beals, Priestley, Alsberg, González, Fitzgibbon... (paper)

Essays in Pan-American, by Joseph B. Lockey . (cloth)

Beside the River Sar: Selections from En las Orillas del

Sar by Rosalía de Castro, translated by S. G. Morley ..................... (cloth)

Sonnets and Poems of Antbero De Quental, translated

by S. G. Morley .................. (cloth)

Studies in the Administration of the Indians of New

Spain, by L. B. Simpson............. Vol. I \& II

Vol. III

Vol. IV

1.75

In Press

AND OTHERS. WRITE FOR LIST.

ORDERS SHOULD BE SENT TO THE BERKELEY OFFICE

The University of California Press Berkeley and Los:Angeles, California 


\section{$M E M \bigcirc R I A$}

DEL PRIMER CONGRESO INTERNACIONAL DE CATEDRATICOS DE LITERATURA IBEROAMERICANA

Publicada por

UNIVERSIDAD NACIONAL

INSTITUTO INTERNACIONAL DE

Autónoma DE México

LITERATURA IBEROAMERICANA

Prefacio de Manuel Pedro González

UN TOMO DE MÁS DE 200 páGINAS, \$1.50

Pedidos a:

UNIVERSIDAD NACIONAL AUTONOMA DE MEXICO

Selected reading texts on different levels

$\square$ LA fuente de las calaveras. Pattison.

A Mexican mystery. An exciting story for third term reading.

Published in Match, 1944

CONTOS DO BRASIL. Hamilton and FaHs.

Sixteen Portuguese stories by contemporary authors. Graded in difficulty.

Published in March, 1944

LOS DE ABAJO. (AzueLA) Englekirk and Kiddle. An annotated edition of the famous Mexican novel with Introduction.

181 pages, $\$ 1.40$

DOÑa BÁRBara. (Gallegos) Dunham.

Edited for students on an intermediate level. Glossary and notes.

280 pages, $\$ 1.75$

AN OUTLINE HISTORY OF SPANISH AMERICAN

LITERATURE. Second Edition Hespelt, Leonard, Reid, Crow, and Englekirk.

The authoritative guide to authors, works, criticism, etc., by periods and genres.

Write for complete catalogue.

F. S. CROFTS \& CO.

101 Fifth Avenue. New York 3, N. Y. 
The ANTOLOGIA POETICA of MANUEL GONZALEZ PRADA, first in the series CLASSICS OF LATIN AMERICA to be published under the auspices of the International Institute of Ibero-American Literature, is now for sale at $\$ 2.50$.

The anthology contains nearly 400 pages, is beautifully printed, carries an excellent introduction and many notes by Carlos García-Prada, and is to date the finest single volume representing the works of the famous Peruvian master.

COPIES ARE IIMITED, SO PLEASE PLACE ORDERS AT ONCE WITH NINA IEE WEISINGER, UNIVERSITY OF TEXAS, AUSTIN, TEXAS.

\section{OBRAS POSTUMAS DE GONZALEZ-PRADA}

Trozos de vida (1933) - Poemas ..........\$1.00

Bajo el oprobio (1933) - Panfleto contra las tiranías

militares en América Latina .............. 0.75

Baladas peruanas (1935) - Poemas ........... 0.50

Anarquía (1936) - Artículos sociales ......... 0.50

Nuevas páginas libres (1937) - Ensayos ........ 0.75

Grafitos (1937) — Epigramas ............... 1.25

Figuras y figurones (1938) - Artículos políticos .... 0.75

Libertarias $(1938)$ - Poemas ............... 1.00

Propaganda y ataque (1939) - Artículos religiosos y po-

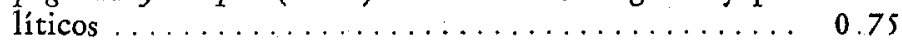

Baladas (1939) - Poemas ............... 1.50

De venta en

LA PRENSA, 245 Canal Street, New York.

Para remitir por correo, por cada libro.... 15 centavos

" C. O. D. " " " $\quad \ldots 25 \quad$ "

No envie dinero suelto por correo. - Use cheque o giro postal. 

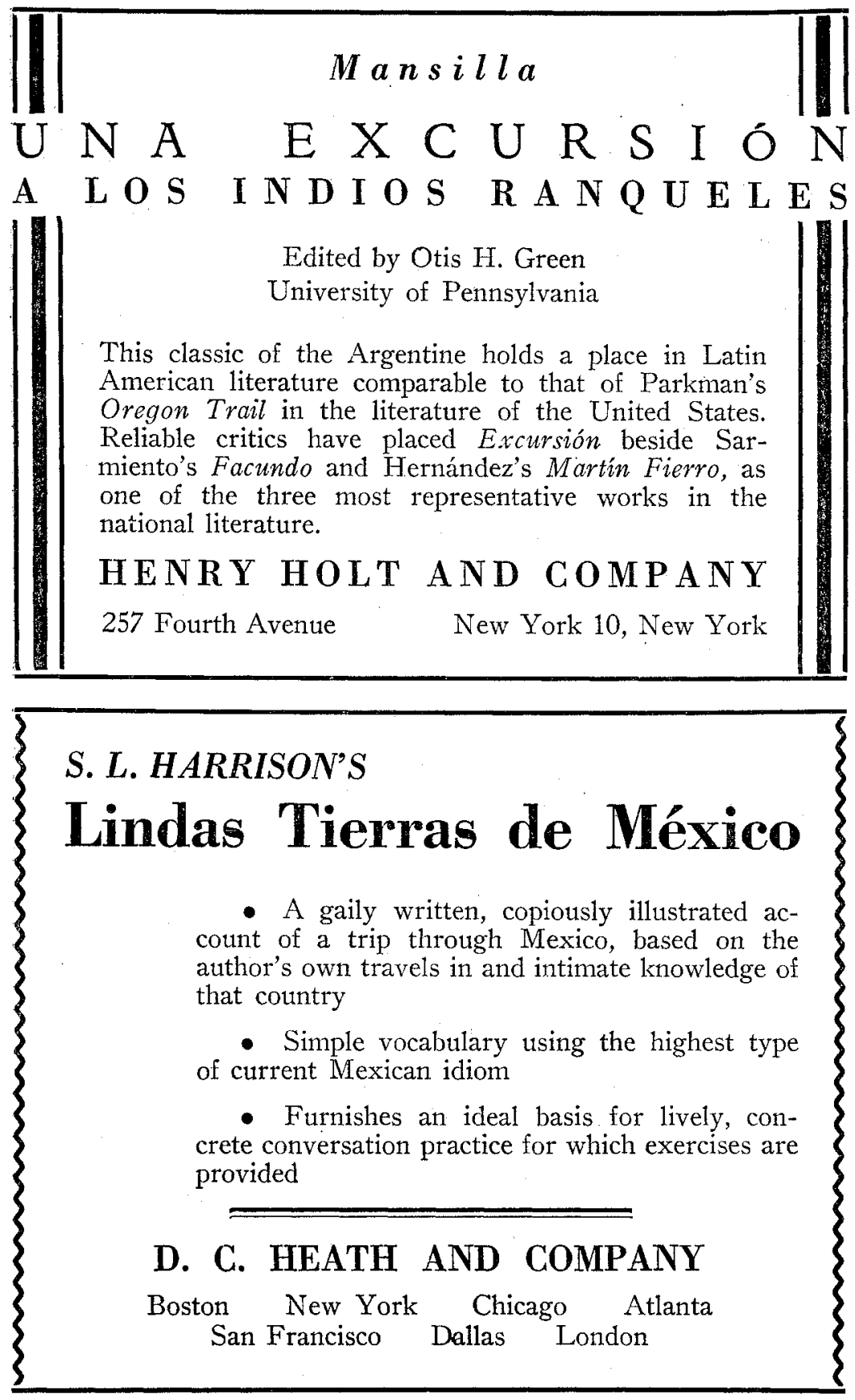


\section{THE SPANISH TEACHERS' JOURNAL H I S P A N I A}

Established 1917.

AURELIO M. ESPINOSA, Editor 1917-1926;

ALFRED COESTER, Editor 1927-1941.

Published by the American Association of Teachets of Spanish.

Editor, HENRY GRATTAN DOYLE, The George Washington University, Washington, D. C.

Associate Editots, William Berrien, Michael S. DONLAN, AureLIO M. ESPINOSA, JR., CARLOS GARCÍA-PRADA, E. HERMAN HFSPELT, WALTER V. KAULFERS, FRANCIS M. KERChEVILLE, JOHN T. REID, JAMES O. SWAIN.

Business Managet, EMILIO L, GUERRA, Benjamin Franklin High School, New York City.

HISPANIA appears four times a year, in February, May, October, and December. Subscription (including membership in the Association), $\$ 2.00$ a year; foreign countries, 40 cents additional for postage. Each number contains practical and scholarly articles for teachers of Spanish and Portuguese, including helpful hint for teachers new to the field. A sample copy will be sent on request to the Secretary-Treasurer of the Association. Addres subscriptions and inquiries about membership to: GRAYDON S. DELAND, Secretary-Tteasuter, American Association of Teachers of Spanish, Denison University, Granville, Ohio.

HISPANIA is an ideal medium through which to reach the organized Spanish teachers of the United States. For advertising rates, address the Business Managet.

Articles, news notes, and books for review should be addressed to the Editor.

\section{A LA UNIDAD POR LA CULTURA}

America

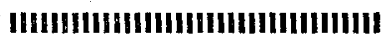

HABANA, CUBA DIRECCION Y ADMINISTRACION Paseo de Martí 116 TELEFS: $\left\{\begin{array}{l}M-9665 \\ M-3700\end{array}\right.$

REVISTA DE LA ASOCIACION DE ESCRITORES Y ARTISTAS AMERICANOS

PRECIO DE SUSCRIPCION $\$ 2.00$ DOLARES 


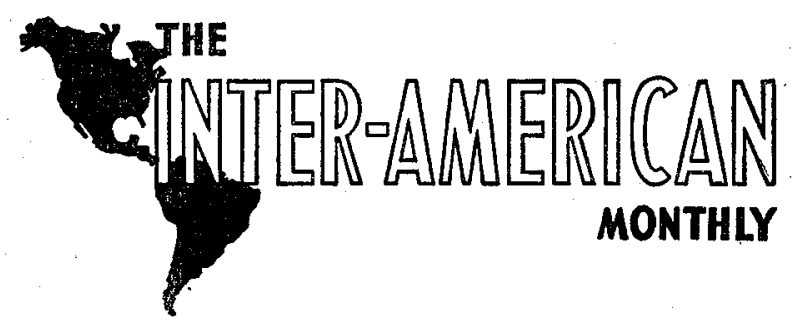

A new publication devoted to reporting and interpreting life in the Americas. Edited by John I. B. MeCulloch, former editor of Pan American News and The Inter-American Quarterly - and incorporating both publications.

The Inter-American Monthly is an invaluable source of timely information on politics, headline personalities, art, music, literature, trade and finance, education - comprehensive, authoritative, and realistic.

Free sample copy on request.

Subscription rates: 3 years $-\$ 7,2$ years $-\$ 5$,
1 year $-\$ 3$,

Special rates for classroom use.

THE INTER-AMERICAN MONTHLY

1200 National Press Bldg.

Washington, D. C.

TULANE UNIVERSITY, colocada estratégicamente en la ciudad de New Orleans, se interesa vitalmente en el desarrollo de una fraternidad más cordial entre las Américas, y por medio de su departamento de español y su Instituto de Middle American Research trabaja hacia este fin. La Universidad saluda al Instituto Internacional de Literatura Iberoamericana como a una organización dedicada al mismo ideal, según se lee en su lema: A LA FRATERNIDAD POR LA CULTURA.

THE TULANE UNIVERSITY OF LOUISIANA

$\mathrm{New}$ Orleans 
BE SURE - anticipate 1944 requirements

DON'T FAIL to send us your Desiderata

REMEMBER we specialize in LATIN AMERICANA

$-\infty \mathrm{Oo}-$

FOREIGN \&

INTERNATIONAL

BOOK CO., INC.

America-South-of-U.S.

110 East 42nd Street.

New York 17, N. Y.
FRANZ C. FEGER

70 Fifth Avenue

NEW YORK 11, N. Y.

Blanco Villalta: Conquista del Río de la Plata. B. A., 1943.

Echagüe, J. P.: Por donde corre el zonda. B. A., 1940 las mejores poesías cubanas. La Habana, 1943

Gallegos, Gerardo: Beau Dondón conquista un mundo. La Habana, 1943

Hays: Twelve Spanish A merican Poets. 1943

Monterde, Francisco: El temor de Hernán Cortés. México, 1943.

\section{NOTICE TO MEMBERS}

PLEASE patronize our advertisers and thus contribute to the financial support of your institute. Our advertisers have splendid collections of Latin American books at prices no higher than you would pay elsewhere. When ordering from them, please mention the REVISTA.

THANK YOU

\section{LIBRERIA "CERVANTES" DE JULIO SUAREZ}

Lavalle, 558

Buenos Aires

LIBROS ANTIGUOS Y MODERNOS, RAROS Y CURIOSOS, REFERENTES A IA AMERICA DEL SUR

Sección especial al servicio de NOVEDADES

(Historia, Literatura, Derecho, Ciencias y Artes)

en las condiciones más ventajosas

Unica agencia de la

REVISTA IBEROAMERICANA, en la Argentina

OLD AND RARE

LATIN AMERICAN BOOKS 